\title{
News from the Tenure Front
}

\section{Cathy A. Trower}

Cathy A. Trower is o research ossociate at the University of Maryland at College Park. She is currently working on a notional study on tenure funded by the Pew Charitable Trusts, where she has spent the past year and a half researching tenure and its alternotives. E-mail: c171@vmoil.umd.edu.

\section{THE STATISTICS}

$\mathrm{I}^{\mathrm{s}}$ should be noted at the outset that tenure systems are the predominant employment practice at most US . colleges and universities. According to the most recent study published by the U.S. Department of Education, tenure systems exist in 71 percent of all higher education institutions. Indeed, virtually all public research, private research, public doctoral, and public comprehensive institutions had tenure systems for full-time instructional staff. In fall 1992, . 58 percent of all permanent full-time instructional faculty and staff had tenure. Another $\mathbf{2 4}$ percent were on the tenure track.'

\section{THE HEADLINES}

"Tenure faces biggest test as debate spills beyond academe and UT regents order tenure reviews." "Academic job security threatened as anti-tenure wave sweeps U.S." "New concerns over the meaning and value of tenure." "Tenured and untouchable." "Tenure: Not Just Job Security." These are some of the headlines from newspaper stories and magazine articles across the United States.

\section{T H E ATTACK}

Business Leaden. Tenure, a bulwark of academic life is currently under attack from constituencies both inside and outside academe. "Why should faculty enjoy lifetime employment security when virtually no one else has it?"ponders the former IBM vice president, now "downsized"into early retirement. Given the recent layoffs of enormous numbers of business professionals, academia's tenure system seems, a tbest, anachronistic. "Academia is much more out of step than we ever were before with the commercial sector," says Derek Hodgson, provost and vice president for academic affairs at Mississippi State University.

Boards and Legislators. Frustrated trustees are asking questions. How can we manage effectively during difficult financial times with tenure policies that restrict our ability to move resources fluidly? Have the costs and benefits of tenure changed since its inception to current times? Has traditional tenure outlived its usefulness, its purpose? Recently, collegeboard members across the country have questioned tenure policies in light of fiscal realities. They wonder what to do when market demand shifts from one program to another, or from one campus to another. In 1995, the Arizona Board of Regents, together with the faculty and administrators at Arizona's public institutions, began discussions about these issues. The board became concerned that the state's universities were not being responsive to changing societal demands and that the presence of tenure raised issues of effectiveness and credibility with the general public.

The University of Minnesota Board of Regents found

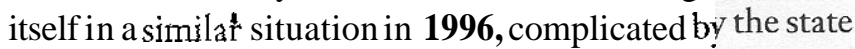
legislature's holding $\mathbf{\$ 6 . 6}$ million in abeyance pen ${ }^{\text {iding ten- }}$ ure reform. There, the faculty senate proposed several modifications to the traditional tenure system-including, but not limited to, the recognition of outreach as a criterion for tenure, posttenure review with the possibility of salary reduction for poor performance; tightened standards for term appointments; the ability to extend the probationary period to nine years; a provision to tie tenure to base salary; and a simplified disciplinary procedure. The state legislaturefelt that the facultyrecommendations "fell short" in three areas: an unclear link between performance and compensation; insufficient flexibility on the part of the university in response to programmatic needs in a changing environment; and a "cumbersome" and "complex" posttenure review process that was "virtuallyunworkable."

The regents proposed that $\mathbf{8}$ of the faculty's 12 proposed motions be fully accepted, and that revisions be made in three areas to meet the requests of state officials. Specifically, the regents wanted greater flexibility for faculty compensation, the imposition of discipline when "adequate cause" exists, and the ability to terminate faculty appointments if reassignment or retraining were impractical in the event of programmatic changes. Feeling that the regents' draft proposal substantially reduced or eliminajed tenure guaranteesin five kev areas. the facultv rejected itand signed enough union cards to trigger a state Iabor order that froze all employment conditions at the University of Alinnesota.

Funior Faculy. "The tenure process seems unfais and arbitrary, All of the tenured slots are occupied; wè can't get into the club. Tenure attainment is virtually inpossible," lament many junior faculty. Indeed, when asked about the academic career, these new and aspiring faculty revealed serious reservations about tenure, but identifiel the tenure process as their most urgent concern. They comnented that expectations are constantly changing, that evrrything is 
vague, ambiguous, and illusive. The process itself is seriously flawed and, because it is such a high-stakes decision for both the institution and the individual, it is essential that the process be restructured.'

\section{THE RESPONSE}

Institutional responses to the attacks on tenure have ranged from maintaining the status quo to overhauling the system, with most institutions taking some actions in between those extremes. In a recent survey with $\mathbf{2 8 0}$ respondents from four-year institutions, 31 percent report no changes to the traditional tenure policies on their campuses.] The remainder, however, report modifications, including posttenure review (29 percent), hiring faculty on long-term nontenure-track appointments ( $\mathbf{2 4}$ percent), stop-the-tenure-clock provisions for probationary faculty (10 percent), lengthening probationary periods ( 5 percent), and imposing tenure quotas (5 percent). Fifteen percent of respondents report their institutions have no tenure system; these colleges hire faculty on multiple-year contracts.

\section{Institutional responses to the atfacks on tenure have ranged from maintaining the status quo to overhouling the sys- tem, with mostinstitutions taking some actions in between those extremes.}

\section{THE FUTURE}

It seems likely that tenure systems will continue to he attacked until the general public, board members, legislators, and junior faculty feel that significant reform has occurred. Major modifications to traditional tenure, including the overhaul of tenure codes, will continue to occur at the less selective institutions, while the elites are likely to continue working at the margins and create new faculty employment tracks. In addition to those modifications previously mentioned, it appears that there are several prime candidates for tenure reform including:

- uncoupling tenure and academic freedom - that is, finding other ways to protect academic freedom for all faculty;

- the creation of more options for faculty - that is, offering an array of employment practices from which faculty may choose, as well as incentives for faculty to forego tenure;

- changes in pretenure policies such as "tenure by objectives"; and

- changes in the locus of tenure such that faculty become tenured in departments or disciplines, rather than in institutions.
Whatever the future holds for tenure policies, one fact is clear. Institutions are making changes in traditional tenure systems in response to constituents who believe that employment policies and practices must evolve as institutions adapt to the constantly changing outside world.

\section{NOTES}

1. R. J, Kirshstein, N. Matheson, Z. Jing, and L.J.Zimbler, Institutional Policies and Practices Regarding Faculty in Higher Education, 1993 (Washington,D.C.: U. S. Department of Education, National Center for Education Statistics,NCES 97-080, 1996).

2. Eugene R. Rice, "Rethinking Faculty Careers: Heeding New Voices," Educational Record (Fall 1996): 26.

3. Cathy A Trower, Tenure Snapshot (Washington, D.C.: American Association for Higher Education. 1996).

\section{'Boston College Program Sponsors READINGs Series ON HIGHER EDUCATION}

The Garland Readings Seriesin Higher Education will he published in mid-1997. This series of seven volumes, under the general editorship of Philip G. Altbach, includes books on a range of key topics in higher education. All of the books include carefully selected readings on aspects of higher education along with a introduction by the editor of each volume. The series will be available in midsummer from Garland Publishing, Inc. 1000A Sherman Ave., Hamden, CT 065 14. The series includes volumes edited by faculty at Boston College as well as others. The following books are included in the series:

1. Issues in Catholic Higher Education,Joseph O'Keefe, SJ,.assistant professor of educational administration, Boston College

2. Latin American Higher Education, Lewis Tyler, director, Latin American Scholarship Program of American Universities, Harvard University and colleagues.

3. Graduate Education, Maresi Nerad, associate dean, Graduate Division, University of California, Berkeley.

4. Student Development, Karen Arnold, associate professor of higher education, Boston College.

5. Organizationand Administration of Higher Education, Ted I. K. Youn, associate professor of higher education, Boston College.

6. European Higher Education, Peter Darvas, Soros Foundation.

7. The AcademicProfession, Philip Altbach, professor of higher education, Boston College, and Dr. Martin Finkelstein, professor of higher education, Seton Hall Universitv. 